\title{
SUBNORMAL TESTICULAR FUNCTION IN A BULL CONCEALED BY PHAGOCYTOSIS OF ABNORMAL SPERMATOZOA IN THE EFFERENT DUCTULES
}

\author{
B. GRABO, B. GUSTAFSSON, L. NICANDER AND A. R. RAO*
}

Departments of Clinical Biochemistry, of Obstetrics and Gynaecology and of Anatomy and Histology, Royal Veterinary College, $S$-104 05 Stockholm, Sweden

(Received 11th March 1971)

Sperm counts from different levels of the male ducts have suggested a selective removal of abnormal spermatozoa in the epididymis (Orgebin-Crist, 1964; LeRoy-Gilette, 1966; Roussel, Stallcup \& Austin, 1967). Phagocytosis of spermatozoa by epithelial cells, however, has rarely been reported (Nicander, 1963) except in cases of epididymal obstruction (cf. Orgebin-Crist, 1969). The present report on frequent phagocytosis of abnormal spermatozoa in the efferent ductules of a bull adds material to the discussion on sperm elimination in the male genital ducts.

The bull was of the Swedish Red and White Breed, 15 months old and purchased as normal. It had served a few times and produced offspring. During 2 months' stay at the clinic, its semen picture was within the normal limits given by Lagerlöf (1934), though the percentage of pathological heads was close to the upper limit (Table 1). After death, material for light and electron microscopy and for chemical investigation (Crabo, 1965) was obtained from testes and epididymides. Sperm morphology was studied quantitatively after fixation in formol saline (Hancock, 1957). Other methods which were used are shown in the tables and legends, and microscope findings in Plate 1.

Table 2 shows that the sample from the rete testis contained a high percentage of detached sperm heads, most of which had disappeared before the proximal part of the epididymal duct was reached.

Electron microscopy of the efferent ductules produced ample evidence of epithelial phagocytosis of broken spermatozoa. Sperm heads and tails in different stages of disintegration were common in the cytoplasm of some nonciliated cells. The possibility that some intact spermatozoa were also phagocytosed could not be excluded. Abnormal sperm heads were numerous in the rete testis and caput epididymidis (see Rao, 1971). Their number decreased in the corpus epididymidis, but selective epithelial phagocytosis of such spermatozoa could not be demonstrated. Adecrease in the percentage of abnormal sperm heads in the efferent ductules and epididymal ducts of bulls was also observed by Rao (1971). The numbers of detached heads in the rete testis of the present bull are abnormally high compared to the findings of Gustafsson \& Crabo (1971) for

* Present address: Department of Obstetrics and Gynaecology, College of Veterinary Science, Tirupati, India. 

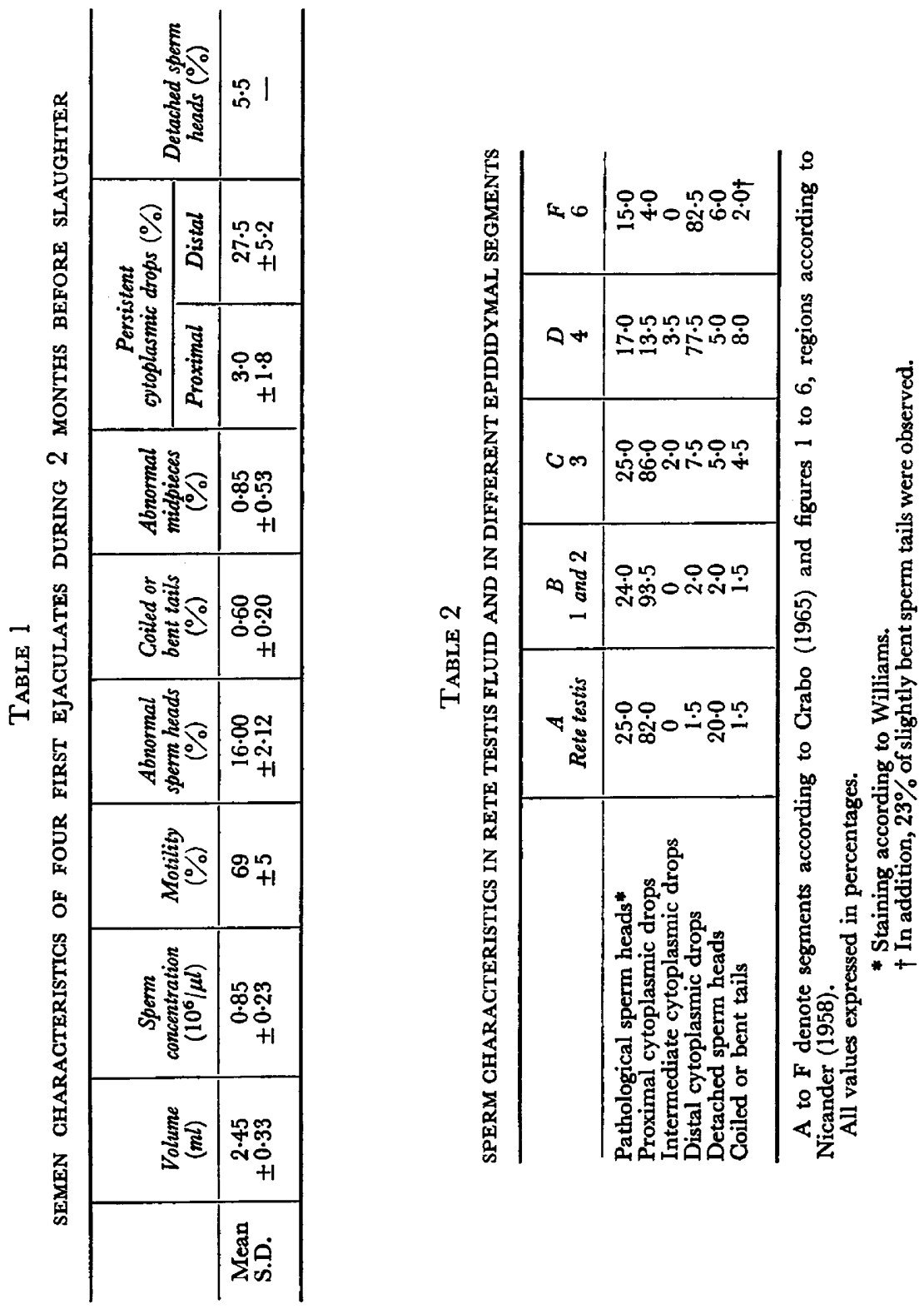
normal bulls: about $0.4 \%$ in the rete with a slight increase in the epididymis. The considerably higher numbers found by Glover (1961), Amann \& Almquist (1962) and Roussel et al. (1967) might be explained on the grounds of differences in technique.

The number of sperm tail defects observed in the epididymal duct of the present case (Table 2) was higher than in normal bulls (Gustafsson \& Crabo, 1971). A variety of chemical changes in the epididymal plasma have been shown to be correlated with increased numbers of detached sperm heads and bent or coiled tails in the lower part of the epididymis (Gustafsson, 1966). Plasma from different epididymal segments of the present bull was analysed for spermatocrit, sodium, potassium, chloride and total protein according to Crabo (1965). The values obtained for sodium (41 mequiv./litre), potassium (34 mequiv./litre) and chloride (21 mequiv./litre) in Segment $\mathrm{F}$ were two standard deviations or more above the mean values for normal bulls (Crabo, 1965 ), and slightly increased also in segment $\mathbf{E}$. The protein concentration was much above normal both in Segment D $(15.5 \mathrm{mg} \mathrm{N} / \mathrm{ml})$ and in Segment F $(11.0 \mathrm{mg} \mathrm{N} / \mathrm{ml})$. There is, therefore, a possibility that the composition of the epididymal plasma of the present bull might reflect an increased sperm disintegration.

It would appear that the semen characteristics of ejaculates can be within physiological limits, though testicular function is subnormal. The original presence of a high number of pathological and detached sperm heads can be concealed by phagocytosis in the ductuli efferentes (and possibly the proximal part of the epididymis). The function of the epididymis in the bull described here was probably abnormal, as judged by the composition of the epididymal plasma, and this should be taken into account in interpreting the results.

\section{REFERENCES}

Amann, R. P. \& Almquist, J. O. (1962) Reproductive capacity of dairy bulls. VI. Effect of unilateral vasectomy and ejaculation frequency on sperm reserves; aspects of epididymal function. $\mathcal{J}$. Reprod. Fert. 3, 260.

Crabo, B. (1965) Studies on the composition of epididymal content in bulls and boars. Acta vet. scand. 6, Suppl. 5.

Glover, T. D. (1961) Disintegrated spermatozoa from the epididymis. Nature, Lond. 190, 185.

Gustarsson, B. (1966) Luminal contents of the bovine epididymis under conditions of reduced spermatogenesis, luminal blockage and certain sperm abnormalities. Acta vet. scand., Suppl. 17.

Gustafsson, B. \& Grabo, B. (1971) Some morphological characteristics of bull spermatozoa at different levels of the epididymis. Nord. Vet.-Med. 23, 114.

Hancock, J. L. (1957) The morphology of boar spermatozoa. $7 l ~ R$. microsc. Soc. 76, 84.

LAGERLÖF, N. (1934) Morphologische Untersuchungen über Veränderungen im Spermabild und in den Hoden bei Bullen mit verminderter oder aufgehobener Fertilität. Acta path. microbiol. scand., Suppl. 19.

LeRoy-Gilette, M. E. (1966) Morphology of bovine epididymal spermatozoa after X-irradiation of testes. Diss. Abstr. 26, 66-2858.

Nigander, L. (1958) Studies on the regional histology and cytochemistry of the ductus epididymis in stallions, rams and bulls. Acta morph. neerl.-scand. 1, 337.

NigandER, L. (1963) Resorption phenomena in the epididymis. (Abstract) Int. F. Fert. 8, 866.

OrGEBIN-Crist, M. C. (1964) Delayed incorporation of thymidine- ${ }^{3} \mathrm{H}$ in epithelial cells of the ductus epididymidis of the rabbit. $\mathcal{F}$. Reprod. Fert. 8, 259. 
Orgebin-Crist, M. G. (1969) Studies on the function of the epididymis. Biol. Reprod., Suppl. 1, 155.

Roussell, J. D., Stallcup, O. T. \& Austin, C. R. (1967) Selective phagocytosis of spermatozoa in the epididymis of bulls, rabbits and monkeys. Fert. Steril. 18, 509.

RAO, A. R. (1971) Changes in the morphology of sperm during their passage through the genital tract in bulls with normal and impaired spermatogenesis. Thesis, Stockholm.

\section{EXPLANATION OF PLATE 1}

Fig. 1. Two sperm heads (arrow) adjacent to the nucleus in an epithelial cell of an efferent ductule. Bouins' fixation, haemalum-eosin. $\times 1000$.

Fig. 2. Pathological sperm head and tail in the cytoplasm of a non-ciliated cell. Glutaraldehyde-osmium fixation, electron micrograph. $\times 20,000$.

FIG. 3. Phagocytosed sperm head deteriorating near the nucleus $(\mathrm{N})$ of an epithelial cell Electron micrograph. $\times 16,000$. 

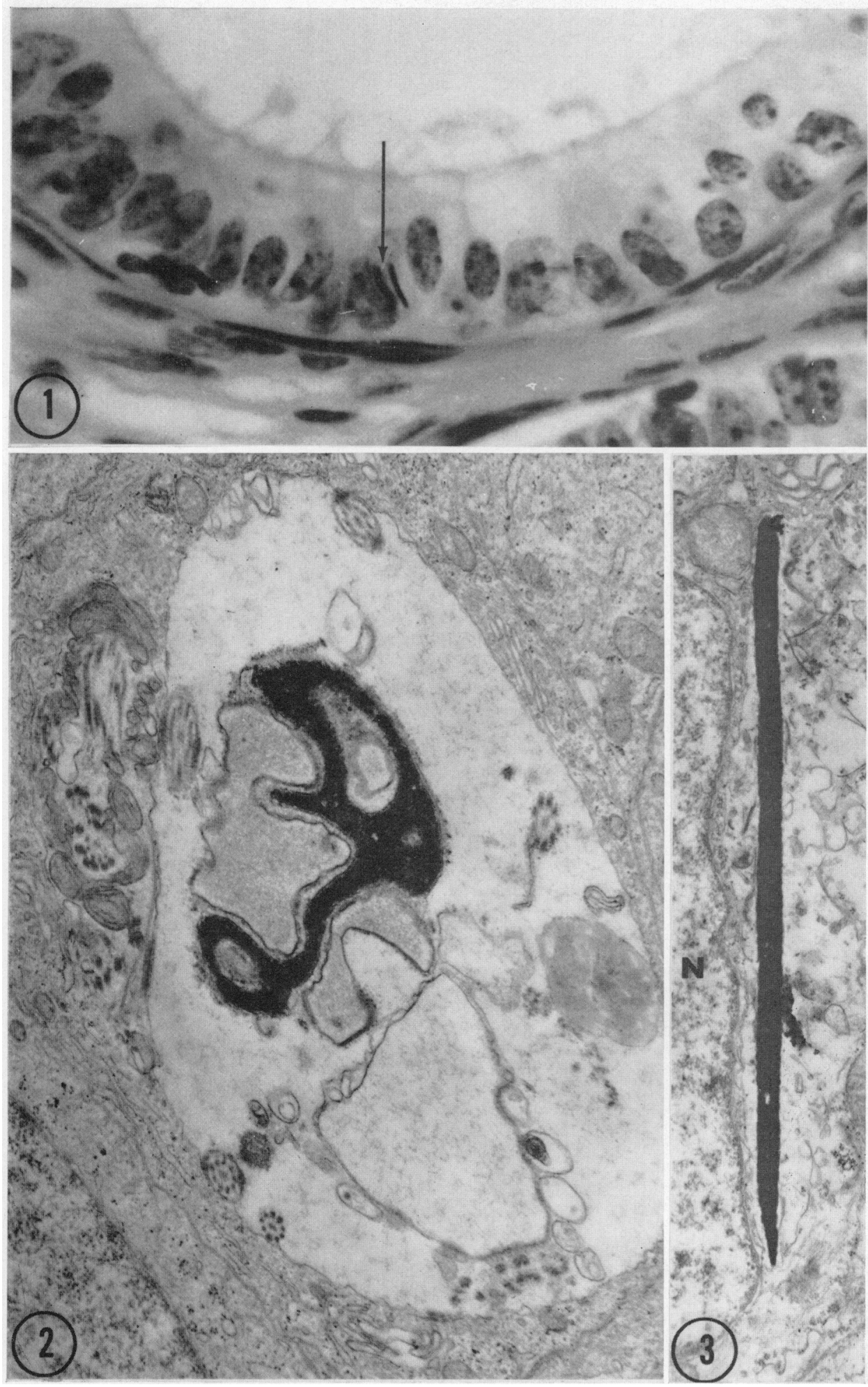